Int. J. Speleol. 16 (1987), pp. 1-16

\title{
The evolution of non-relictual tropical troglobites
}

\author{
Francis G. Howarth *
}

\section{SUMMARY}

The discovery of terrestrial troglobites living in caves on young oceanic islands with close epigean relatives living in nearby surface habitats offers unique opportunities to develop and test hypotheses concerning their evolution. Studies comparing the physiological ecology of troglobites with their epigean relatives suggest that troglobites are highly specialized to exploit resources within the system of interconnected medium-sized voids (mesocaverns) and only colonize cave passages (macrocaverns) with a stable, water vaporsaturated atmosphere. Few other animals can live in the mesocaverns. Rather than being relicts isolated in caves by the extinction of their epigean ancestral population, troglobites appear to evolve by a process called adaptive shift from species that are frequent accidentals in the mesocaverns.

\section{INTRODUCTION}

This symposium is timely, as within only the last two decades there has been a virtual revolution in our thinking on cave biology. This radical change was precipitated by the discoveries of significant troglobitic faunas in tropical caves, in lava tubes, in the smaller voids within fractured subterranean substrates (Howarth, 1983b; Juberthie, 1983), and continues with the recent discoveries in bad air caves (Howarth \& Stone, in prep.). These discoveries open up whole new fields of biospeleological investigations and call into question the theories on cave animal evolution developed from the pioneering studies in temperate limestone caves. No longer can caves be considered a separate biotope from the voids in the surrounding rock. In fact, both an expanded conception of the subterranean biome and the formulation of a new synthesis on the evolution of cave species are now necessary (Howarth, 1983b).

* J. Linsley Gressitt Center for Research in Entomology, B.P. Bishop Museum, P.O. Box 19000-A, Honolulu, Hawaii, 96817 U.S.A. 
In spite of the fact that the most obvious characters displayed by troglobites appear to be reductive (i.e. loss of such conspicuously adaptive organs as eyes, wings, and body color), I believe that more might be learned from studying what they have gained in order to exploit their environment rather than from focusing only on what they have lost.

\section{HAWAIIAN CAVES AND THEIR FAUNAS AS MICROCOSMS FOR EVOLUTIONARY STUDIES}

The relatively young, isolated Hawaiian Archipelago, which arose from the sea floor by frequent volcanism, is an ideal location for studying the evolution and ecology of cave species and formulating a new synthesis. The islands, which are the emergent summits of mammoth submarine volcanoes, are separated from each other by deep straits $50 \mathrm{~km}$ or more wide. The eight main islands become progressively older as one moves northwest and range in age from 6 million years for Kauai to less than a million years for the youngest, largest and still volcanically active, Hawaii (Mac Donald et al., 1983). Each island or close group of islands is like a mini-continent, since its whole terrestrial biota is derived solely from across water colonists. Swarms of closely related species exploit different habitats, and some of the best examples of adaptive radiation anywhere (Simon et al., 1984; Carson \& Templeton, 1984) are found in the Hawaiian Islands.

The Hawaiian cave animals also fit this pattern of adaptive radiation, and 43 species of terrestrial troglobites are now known (Table 1). They are not evenly distributed but, surprisingly, are most diverse on the younger islands, with 24 species known from Hawaii, 14 from Maui, 2 each from Molokai and Kauai, and 1 from Oahu. They evolved independently from different ancestors on each island, but at least 10 native radiating groups evolved cave species through parallel evolution on separate islands (Table 2). Such independently evolved communities, exploiting similiar resources and physical environments, offer unique opportunities to develop and test hypotheses about their evolution. Furthermore, many of these highly specialized cave species have close epigean relatives still extant living in nearby surface habitats. These provide species pairs for comparative studies on cave adaptation.

Three of the better studied examples (cixiid planthoppers, gryllid crickets and lycosid spiders) will illustrate this point. Within the cixiid genus Oliarus, there are about 80 endemic 
Table 1 - Ecological roles and evolutionary relationships of the terrestrial troglobites of the Hawaiian Islands.

\begin{tabular}{ccc}
\hline Taxa & $\begin{array}{c}\text { Ecological } \\
\text { Role }\end{array}$ & $\begin{array}{c}\text { Extant native } \\
\text { relatives* }\end{array}$ \\
\hline
\end{tabular}

Hawaii Island

Haplophiloscia laevis (Isopoda)

Erigone stygius (Araneae)

Erigone sp. 1(?) (Araneae)

Lycosa howarthi (Araneae)

Oonops (?) sp.

scavenger

predator

predator

predator

predator

Tyrannochthonius howarthi (Pseudoscorpionida) predator

Lithobius (?) sp. 1 (Chilopoda)

Dimerogonus (?) sp. 1 (Myriapoda)

Protanura hawaiiensis (Collembola)

Sinella yoshia (Collembola)

Caconemobius varius (Orthoptera)

Caconemobius sp. 1

Caconemobius sp. 2

Thaumatogryllus cavicola (Orthoptera)

Thaumatogryllus sp. 1

Anisolabis howarthi (Dermaptera)

Speovelia aaa (Heteroptera)

Nesidiolestes ana (Heteroptera)

Oliarus polyphemus (Homoptera)

Oliarus sp. 1

Oliarus sp. 2

Schrankia sp. 1 (Lepidoptera)

Schrankia sp. 2

Unknown family (Lepidoptera)

Maui Island

Hawaiioscia parvituberculata (Isopoda)

Meioneta gagnei (Araneae)

Tyrannochthonius sp. 1 (Pseudoscorpionida)

Lithobius (?) sp. 2 (Chilopoda)

Dimerogonus (?) sp. 2 (Myriapoda)

Sinella sp. 1 (Collembola)

Caconemobius howarthi (Orthoptera)

Caconemobius sp. 2

Thaumatogryllus sp. 2 (Orthoptera)

Thaumatogryllus sp. 3

Oliarus priola (Homoptera)

Oliarus sp. 3

Mecyclothorax (?) sp 1 (Coleoptera)

Schrankia sp. 3 (Lepidoptera)

Molokai Island

Lithobius (?) sp. 3 (Chilopoda)

Oliarus sp. 4 (Homoptera)

\section{Oahu Island}

Tyrannochthonius pupukeanus (Pseudoscorp.) predator

Kauai Island

Spelaeorchestia koloana (Amphipoda)

Adelocosa anops (Araneae) predator

fungivore

omnivore

scavenger

omnivore

omnivore

omnivore

omnivore

omnivore

predator

scavenger

predator

sapsucker

sapsucker

sapsucker

root feeder

root feeder

root feeder

scavenger

predator

predator

predator

fungivore

scavenger

omnivore

omnivore

omnivore

omnivore

sapsucker

sapsucker

predator

root feeder

predator

sapsucker

? parapatric

scavenger

predator parapatric

allopatric

none known

sympatric

sympatric ?

parapatric

?

allopatric

? parapatric

parapatric

troglobite ?

troglobite ?

sympatric

sympatric

sympatric

allopatric

allopatric

parapatric

none known

parapatric

parapatric

parapatric

parapatric

sympatric

sympatric

unknown

none known

unknown

allopatric

? parapatric

parapatric

troglobite

parapatric

allopatric

allopatric

allopatric

parapatric

parapatric

? parapatric

parapatric

? allopatric

? allopatric

* "Sympatric» indicates that a related species (either troglobitic or troglophilic) occurs in caves with the listed species. "Parapatric" indicates that a related species occurs in neighboring habitats, and " allopatric" indicates that all related species are geographically isolated from the listed species. 
Table 2 - Numbers of epigean, troglobitic and troglophilic species among the adaptively radiating native taxa that have independently invaded caves on more than one island. *

\begin{tabular}{|c|c|c|c|c|c|c|}
\hline No. of spp. & Epigean & Hawaii & Maui & $\begin{array}{l}\text { Island } \\
\text { Molokai }\end{array}$ & Oahu & Kauai \\
\hline Philosciidae & $?$ & $1 \mathrm{~TB}$ & $1 \mathrm{~TB}$ & - & - & $?$ \\
\hline Linyphiidae & 5 & $2 \mathrm{~TB}$ & $1 \mathrm{~TB}$ & - & - & - \\
\hline Lycosidae & 10 & $1 \mathrm{~TB}$ & - & - & - & $1 \mathrm{~TB}$ \\
\hline Chthoniidae & - & $1 \mathrm{~TB}$ & $1 \mathrm{~TB}$ & - & $1 \mathrm{~TB}$ & - \\
\hline Lithobiidae & 10 & $1 \mathrm{~TB}$ & $1 \mathrm{~TB}$ & $1 \mathrm{~TB}$ & - & - \\
\hline Cambalidae & 12 & $1 \mathrm{~TB}$ & $1 \mathrm{~TB}$ & - & - & - \\
\hline Entomobryini & $?$ & $1 \mathrm{~TB}$ & $1 \mathrm{~TB}$ & - & - & - \\
\hline \multicolumn{7}{|l|}{ Gryllidae } \\
\hline Caconemobius & 4 & $3 \mathrm{~TB}$ & 2 TB & - & - & - \\
\hline Thaumatogryllus & 3 & $2 \mathrm{~TB}$ & $2 \mathrm{~TB}$ & - & - & - \\
\hline Cixiidae Oliarus & 80 & 3 TB & $2 \mathrm{~TB}$ & $1 \mathrm{~TB}$ & - & - \\
\hline Noctuidae Schrankia & 12 & $\begin{array}{l}2 \mathrm{~TB}, \\
3 \mathrm{TP}\end{array}$ & $\begin{array}{l}1 \text { TB, } \\
1 \text { TP }\end{array}$ & $1 \mathrm{TP}$ & $1 \mathrm{TP}$ & $1 \mathrm{TP}$ \\
\hline
\end{tabular}

${ }^{*} \mathrm{~TB}=$ troglobitic; $\mathrm{TP}=$ troglophilic. Numbers of epigean native Hawaiian species appproximate.

Hawaiian species of which four or five separate lines have invaded caves (Howarth, 1986). Three troglobites, O. polyphemus Fennah and two undescribed species, occur allopatrically on Hawaii Island. O. polyphemus and one of the undescribed species are closely related to $O$. inaequalis Giffard, an epigean species in Hawaii Island rain forests (Fennah, 1973; Howarth, 1986). The other Hawaii Island troglobite is not closely related to $O$. inaequalis. Two unrelated cave species occur on Maui Island, $O$. priola Fennah and an undescribed species. One undescribed troglobitic species occurs on Molokai Island.

At least eight species of true crickets are restricted to $\mathrm{Ha}-$ waiian caves. These belong to the Gryllidae and are not at all related to the continental cave crickets (Gurney \& Rentz, 1978; Howarth, 1981). Members of the genus Thaumatogryllus belong to the native Hawaiian tree crickets, and the cave species prefer to forage on the ceiling. There are small-eyed and blind populations in caves on both Maui and Hawaii islands. The rock crickets, genus Caconemobius, prefer to forage on the floor and walls of caves. On Hawaii Island C. varius Gurney \& Rentz and an undescribed sympatric species are closely related to each other and to C. fori Gurney \& Rentz (Howarth, 1981). The latter species is restricted to young unvegetated lava flows on Hawaii Island (Howarth, 1979) and is thus parapatric to the cave species. The troglobitic C. howarthi Gurney \& Rentz and an allopatric species in caves on Maui Island are closely related to an undescribed halophilic species, which lives on rocky seacoasts on all the main Hawaiian Islands. 
The wolf or big-eyed hunting spiders, family Lycosidae, are among the best sighted spiders, and it would seem axiomatic that none would become cave-adapted (Gertsch, 1973). However, they are good long-distance dispersers, and Hawaii has a diverse and interesting epigean lycosid fauna. In lava tubes on Hawaii Island there lives the troglobitic small-eyed, big-eyed hunting spider, Lycosa howarthi Gertsch. But even more remarkable, there exists in a small area on the old island of Kauai another cave-adapted species, the rare no-eyed, big-eyed hunting spider, Adelocosa anops Gertsch, which, in spite of its appearance and cave adaptations, evolved independently from a different ancestor than did L. howarthi.

The ancestors of the Hawaiian cave animals were preadapted for cave-life and primarily inhabitated two distinct epigean habitats: rain forests and wet rocky substrates. The Thaumatogryllus crickets, Oliarus planthoppers, Nesidiolestes thread-legged bugs, and Schrankia moths all have close relatives living in rain forest habitats. All known Caconemobius crickets occur only on wet rock habitats: new lava flows, sea coasts, cliff faces, and caves. The epigean lycosid spiders occur in both rain forests and rocky substrates. The ancestor of Speovelia aaa Gagne \& Howarth remains unknown but probably was a sea coast species, like its congener, $S$. maritima in Japan.

Most of the troglobites are known from the youngest volcanoes on Hawaii Island, and they colonize new caves surprisingly fast. In fact, the most diverse cave with 11 troglobitic species is Kazumura Lava Tube, which is only 500 years old. A troglobitic Caconemobius cricket was collected in 1980 within a 6-year old lava tube in the 1974 Mauna Ulu eruption on Kilauea. Oliarus polyphemus inhabits a cave in the 1919 lava flow in Kilauea Caldera, even though the flow is still virtually unvegetated. The 100-year old Emesine Lava Tube already supports at least 7 troglobitic species. These observations support the hypothesis that troglobites can live in and disperse through the medium-sized voids (the mesocaverns) within young lava. The geological evidence also supports this as young lava has numerous suitable voids (MacDonald et al., 1983).

\section{COMPARATIVE PHYSIOLOGICAL ECOLOGY OF HAWAIIAN TROGLOBITES}

The almost universal observation that terrestrial troglobites display extreme sensitivity to relative humidity changes and, that cave populations are restricted to passages with stable air saturated with water vapor, provides a big clue to interpreting their 
evolution (Howarth, 1980). In order to understand this relationship and answer the questions «How? " and "Why? ", my colleagues and I have been studying the climate of Hawaiian caves and correlating that with the distribution and environmental physiology of the troglobites and their surface relatives.

Charcoal Cave, at about $800 \mathrm{~m}$ elevation, on the south slopes of Kilauea, Hawaii Island, was selected for more detailed environmental studies. The large main passage, about $250 \mathrm{~m}$ long, trends gently down slope from its single large entrance. The large entrance allows the effects of surface climatic events to enter the cave and affect a large portion of the cave. Preliminary surveys showed that the distribution of cave animals was dynamic and associated with the moisture supply within the cave. In order to test this hypothesis, 3 weather stations, each consisting of a recording hygrothermograph and two piche atmometers were set $45 \mathrm{~m}, 110 \mathrm{~m}$, and $185 \mathrm{~m}$ from the entrance within the twilight, transition, and deep cave zones respectively. As expected, the resulting data demonstrated the dynamic nature of the cave environment and the relationship between the environment and the distribution of troglobites (Howarth, 1983a).

The climatic events within the cave are correlated with events on the surface but with sometimes considerable temporal variation. Simple diffusion of water vapor is too slow to significantly affect the cave environment. The major changes in the relative humidity of the cave are precipitated by the movement of air masses into and out of the cave both along density gradients and pushed by surface winds. The effect of the incoming air on the relative humidity within the cave depends on its moisture content relative to that in the cave. The relative humidity in the cave most commonly plummets at night when the colder (and therefore drier) surface air sinks into the cave. This is the tropical winter effect (Howarth, 1980). Incoming surface air reaches the deep cave zone within minutes but becomes saturated by evaporation from the moist walls and falling water drops. The wave of unsaturation becomes attenuated and takes one to two hours to move from the twilight zone station to the deep cave zone station. The more water available the greater the attenuation and time lag. The time lag and buffering are also greatly modified by the passage size and shape.

The potential evaporation rate at the 3 stations correlated well with the degree of change in relative humidity. The rate of potential evaporation at the deep cave station was only $36 \%$ of the rate at the transition zone station and $8 \%$ of the rate at the twilight zone station. Compared to the arid surface environment, the twilight zone was still quite humid. The potential 
evaporation rate on the surface outside of the cave was at least 5 times the rate at the twilight zone station. During the period of study, specialized cave animals were found only beyond $165 \mathrm{~m}$ from the entrance. Thus the boundary between the transition zone and deep cave zone has a calculated potential evaporation rate of $0.16 \mathrm{~cm}^{3}$ day -1 . The evaporation rate within the mesocaverns would be considerably less than this value. The boundary between the transition and deep cave zones is dynamic, and many troglobites migrate in response to the humidity changes. Most troglobites appear to exploit resources in caves only on temporary forays from their more humid retreats, unless the cave passage has an exceptional environment (see below).

We have also compared the water balance physiology of the cave spider (Lycosa howarthi) (Hadley et al., 1981) and crickets (Caconemobius varius and C. howarthi) (Ahearn \& Howarth, 1982) with their close surface relatives. These studies corroborate the field studies and indicate that the cave species have adapted to a hydrating environment.

The relative rates of water loss by these epigean and cave species are clearly correlated with the availability of water in their respective environments. The cave spider and cricket, which live side by side in lava tubes, have almost identical permeabilities of 33.4 and $34.5 \mu \mathrm{g} \mathrm{cm}-{ }^{2}$ hour- ${ }^{-1} \mathrm{mmHg}^{-1}$ (Hadley et al., 1981; Ahearn \& Howarth, 1982). The surface spider, Lycosa sp., lives in the driest environment and loses water at $1 / 10$ th the rate $\left(3.1 \mu \mathrm{g} \mathrm{cm}{ }^{-2}\right.$ hour $\left.{ }^{-1} \mathrm{mmHg}_{-}{ }^{1}\right)$ of the cave species (Hadley et al., 1981). The 2 epigean crickets are intermediate, and significantly, the halophilic beach cricket, which rarely strays from its damp 98\% $\mathrm{RH}$ littoral environment, loses less water than the cave species, indicating that the terrestrial cave environment is considerably more hydrating than marine environments (Ahearn \& Howarth, 1982). These data suggest that there is selection pressure on terrestrial cave species to adapt to an atmospheric moisture content above the equilibrium humidity of insect hemolymph (i.e. 99.0-99.5\% RH). They have become freshwater aquatic animals living in an aereal environment.

\section{THE DISTRIBUTION OF TROGLOBITES WITHIN} $A$ « BAD AIR CAVE

Recently, I have been comparing our Hawaii results with the ecology of both limestone caves and lava tubes in tropical north Queensland, Australia, (Howarth \& Stone, in prep.). Here we have found a lava tube (Bayliss Cave) with a clear zonation 
of troglophilic and troglobitic species correlated with abiotic environmental parameters, especially the concentration of $\mathrm{CO}_{2}$. This zonation results from the location of the single constricted entrance at its upper end, passage configuration, and availability of moisture and organic matter.

Two constrictions trap the cave air into three compartments: an outer transition zone from the entrance to the Duckunder (where the passage height dips to $1.5 \mathrm{~m}$ ) $345 \mathrm{~m}$ into the cave; a middle zone, $345-630 \mathrm{~m}$ from the entrance between the Duckunder and the Wall (a large dam of rocks across the passage); and an inner zone beyond the Wall. As the lighter warm cave air and water vapor rise towards the entrance, they become trapped by the Duckunder. The downward sloping cave acts as a trap for biogenically generated $\mathrm{CO}_{2}$. The cave is mesotrophic to eutrophic with abundant living and dead tree roots, bat guano, dead animals, and washed in organic matter.

The distribution of the 51 species of terrestrial arthropods resident in the cave is clearly related to the environment. During our surveys in May and June, 1985 and 1986, a community composed almost entirely of troglobites occurred downslope of the Duckunder. Three-fourths of the 24 troglobitic species lived only in the middle and inner zones where the atmosphere was saturated with water vapor and where the elevated $\mathrm{CO}_{2}$ concentrations (up to 200 times ambient) were approaching limiting values for surface and many troglophilic species. Most other tropical and temperate cave passages that I have studied resemble the transition zone upslope of the Duckunder, both in their abiotic environment and in the percentages and behaviors of troglobitic species. The environments of most lowland tropical caves are severely affected by the tropical winter effect and the presence of large or multiple entrances. In a few caves one can approach an environment similar to that near the Duckunder, and these often lower-level, dead end passages also contain a high diversity of troglobitic species (Howarth, 1980; Chapman, 1986). The long-term stable inner air mass in Bayliss Cave approaches equilibrium with the atmosphere of the surrounding mesocaverns. The occurrence of a community of troglobites in the "bad air" section of the cave supports the hypothesis that troglobites are specialized to exploit the resources in the medium-sized voids where gas mixtures, especially $\mathrm{CO}_{2}$ and water vapor, are limiting for most surface species. The increased integumental permeability and the reduced metabolic rate observed in cave animals may be adaptations, respectively, to the hydrating environment (Ahearn \& Howarth, 1982), and to the low $\mathrm{O}_{2}$ and correspondingly high $\mathrm{CO}_{2}$ concentrations in their environment (Howarth, 1983b; Hüppop, 1986). 


\section{ADAPTIVE SHIFT VERSUS ISOLATION HYPOTHESES IN TROPICAL TROGLOBITIC EVOLUTION}

The initial studies in temperate regions indicated that the ancestors of troglobites became isolated in caves after local extinction of their surface populations by changing climates, especially those associated with glaciation (Barr, 1968; Sbordoni, 1982; Barr \& Holsinger, 1985). Without this isolation it was assumed that immigration from surface populations would swamp any incipient adaptations to the cave environment. To their credit, biospeleologists were among the first to recognize the importance of extinctions in shaping evolution and ecology. Extinctions are finally getting their due in theoretical ecology and evolution (Fowler \& MacMahon, 1982).

The discovery of terrestrial troglobites living sympatrically or parapatrically with their close surface relatives on young oceanic islands is, therefore, surprising and indicates that extinction of the surface population may not be a prerequisite of cave adaptation. If they are not relicts, how do the ancestors of troglobites initially become isolated in caves?

A big clue comes from the young Hawaiian lava tubes. When a large lava flow advances it often surrounds and leaves unscathed "islands" of older substrates isolated in the flow. These "islands", called kipuka in Hawaii, are a common phenomenon on the younger volcanoes. Young lava flows are veritable deserts to the rain forest animals living in the adjacent kipuka, such as the cixiid planthopper, Oliarus inaequalis. These rain forest animals cannot colonize lava flows until a mature rain forest develops. However, going underground within these young lava flows (such as Emesine Cave in the 1881 lava flow above $1500 \mathrm{~m}$ elevation on Mauna Loa), one discovers that the few scattered shrubs one metre tall on the surface have massive root systems at least $5 \mathrm{~m}$ deep in order to maintain themselves in the xeric surface environment (Gagne \& Howarth, 1975; Howarth, 1986). Here is the rain forest, but until a rain forest species can survive, reproduce, and disperse underground, this resource remains entirely out of reach.

Over the millennia millions of transient subterranean populations became (and still are becoming) established. All but a few died out within a few generations. The major bottleneck for survival for many underground populations may have been the ability to locate mates and reproduce underground. Once a population could do this a large new habitat and food resource was opened up to it, and the population could expand rapidly. For a time backcrosses with its ancestors in boundary habitats could have added genetic variability for selection (e.g. Wilkens \& Hüppop, 1986), but note that a change in mating 
behavior, which may be one of the more important adaptive shifts necessary for successful colonization of the caves and mesocaverns, would also effectively isolate the incipient population underground.

Eruptions have been so frequent on Hawaiian volcanoes that new flows and caves are continuously created (MacDonald et al., 1983). These provide not only a large geographical area of cave habitat, but also a dynamic system of new habitats for colonization. Plant roots and other food resources penetrate much deeper into the young flows than in older substrates, so that more food is out of reach of the non-cave species. In fact, in many young cavernous substrates the evolving cave population may be larger than its parental epigean population, so that if swamping occurs it may be by the cave form (Howarth, 1980) rather than by the surface form, as envisioned by Barr (1968).

The subterranean habitat is so novel and the new selection pressures so strong that such new populations diverged morphologically, physiologically, and behaviorly from surface populations, and most have become genetically isolated from their ancestors and highly troglomorphic. The initial successful populations were probably each founded by an adaptive shift by only one or a few individuals, and, therefore, this model of cave adaptation fits both the evidence and the founder effect model of speciation (Carson \& Templeton, 1984).

These kipuka and young lava flow environments are strikingly similar to periglacial, karstic, and montane terrains. In periglacial environments there are often islands of forests developing in protected sites separated by more-or-less barren ground. The extensive deposits of young moraines offer vast mesocavernous habitats for dispersing and evolving troglobites. The release and transport of organic debris trapped within the glacier may provide abundant food resources to periglacial underground habitats. In karst terrains barren rocky ground is often the norm, with leaf litter and vegetation restricted to cracks and sinkholes. In montane terrains the vegetation cover interdigitates with stone deserts on ridges, young rock slides, and rock outcrops. Shifting young talus slopes provide abundant mesocavernous habitats and dispersal routes between and among these vegetated islands.

In all of these cavernous terrains large amounts of organic food energy are continually being brought into the meso- and macro- cavernous voids by percolating groundwater, sinking streams, deeply penetrating roots, dispersing animals, and gravity. Wherever an interconnected mesocavernous system is well-developed, this organic material represents a significant exploitable resource which is largely out of reach to opportu- 
nistic colonizing species, because they cannot cope with the inhospitable environment. It is this potential food resource that provides the driving force for the adaptive shift and evolution of cave species. Once an adaptive shift occurs, establishing a reproducing population underground, then it is both the effects of the strong new selection pressures (especially physiological and behaviorial) and the release from previously strong selection pressures that bring about the remarkable changes that we recognize as troglomorphy. The action of natural selection (including sexual selection) can be intense but is often seriously underestimated in evolutionary models (Carson \& Templeton, 1984; Parsons, 1987).

In this adaptive shift model, troglomorphic populations may evolve parapatrically or narrowly sympatrically from their ancestors (Wilkens \& Hüppop, 1986). However, we must consider evolution as two distinct, independent processes: adaptation, which is continuous with every generation, and speciation. Intuitively, most founder events and adaptive shifts would result in speciation; however, a speciation event may occur at any point during the divergence of two populations. All contingencies appear to be possible, from a speciation event (or even multiple speciation events) near the commencement of divergence, to the evolution of a highly troglomorphic population still capable of interbreeding with its epigean relative, as is the case with the fish, Astyanax fasciatus (Wilkens \& Hüppop, 1986) or even with highly polymorphic species, such as Plastosciara perniciosa (Steffan, 1973).

The assumption that shrinking resources force a population to adapt to a new niche is based on a weak theoretical foundation. New populations and species evolve from a position of strength, since natural selection predicts that populations are becoming better and better adapted to their environment. Richer environments in terms of harvestable energy have a greater potential for colonization and evolution of new species.

In contrast to Wilkens (1986), I see no evidence for a linear relationship between time and degree of loss of any structure. In fact I find such an assumption to be an antithesis of evolutionary biology. For any adapting population the degree of phenotypic reduction of each character will be a function of several factors, including (1) time, (2) degree of pre-adaptation (that is, the character's starting point in the population), (3) its genetic repertoire (that is, the options the population's genotype allows), (4) the degree of positive, negative, and relaxed selection pressures on the structure, (5) degree of pleiotropic effects, (6) total number and interactions of the genes involved in the development of the structure, (7) founder effects, (8) effective population size (that is, deme effects), (9) 
the mutation rate, (10) intensity of novel environmental stresses, (11) the genetic load (that is, the number of deleterious alleles the population already carries for the structure), (12) generation time, (13) genetic drift, (14) extrinsic and intrinsic stochastic events regulating population size, and (15) other genetic factors such as recombination rate, epistasis, transposons, and genetic contaminants. These factors are not mutually exclusive, and I may have missed some, but the important points are that there are many factors involved in the reduction of each structure and that each factor has an independent time component. Thus, a graph of reductive evolution in a population through time may be curvilinear and may have many plateaus, as each structure reduces to a point where positive selection pressures again become more important than reductive trends. Christiansen (1986) found both positive and negative correlations among reductive features in soil and cave Collembola, underscoring the fact that no one theory is likely to explain all reduction.

The three traditional models for explaining reductive evolution (1, the accumulation of neutral mutations, 2, pleiotropic effects, and 3, positive natural selection, especially for energy economy), are often assumed to be antagonistic to each other (Sket, 1986; Culver, 1982). In fact, these factors are probably not mutually exclusive, as reduction appears to be the result of the interaction and integration of a suite of evolutionary processes, including these three. The degree of reduction is correlated with the habitat; therefore, natural selection appears to mold and set the limits on the degree of reduction brought about by genetic processes.

Energy resources are not correlated with the degree of reduction (Poulson, 1986). For example, the food resources (i.e. roots of the native tree Metrosideros polymorpha) for both the cave cixiid (Oliarus polyphemus) and its close surface relative (O. inaequalis) on Hawaii Island are of the same quality and probably the same quantity within the feeding range of an individual; yet the two species show extreme differences in their degree of reduction (Fennah, 1973). The lava flow cricket, Caconemobius fori, shows no reduction yet it lives in an environment with far less visible energy than its close cave relatives (Howarth, 1981). Natural selection and thermodynamics dictate that economy of energy is built into evolutionary processes; i.e., all organisms evolve towards maximal utilization of their resources. Among polymorphic species, the richest food sources are often exploited by the most reduced forms (Steffan, 1973).

Even though cave environments are usually described as food poor (Barr, 1968; Poulson, 1986; Hüppop, 1986), the adapta- 
tions for energy economy displayed by troglobites may be better understood by the spatial and temporal variability in the food supply, as well as its difficulty of exploitation, rather than the total amount. Within underground environments, especially within the mesocaverns, the behaviorial problems inherent in finding even rich food supplies are much more difficult than in most surface environments.

The loss of complex structures and systems under relaxed selection pressure is probably a much faster and more widespread phenomenon than was previously assumed. Recent genetics and molecular biological studies have demonstrated that removing a positive selection pressure from an organ or a gene will cause it to gradually disintegrate under mutation pressure (Carson et al., 1982). The more genes that are involved in a developmental process the faster the process will erode when selection is relaxed (Culver, 1982). Add to this the possibility of deleterious alleles already carried in the population, and the rate increases further. Even eyeless birds have been reported (Berger \& Howard, 1968). Furthermore, among cave populations the mutation rate may increase dramatically due to the occurrence of high natural radiation levels underground. The high karyotypic variability in underground animals (Nevo, 1979) may reflect this phenomenon.

High stress environments may encourage more rapid evolutionary rates, not only from the more severe levels of natural selection but also from an increase of mutations, recombinations, and variability resulting from dysfunction of regulatory mechanisms caused by the stress itself (see review by Parsons, 1987). Organisms adapting to cave environments would be under more stress than their parental population especially since the cave environment would present a number of novel stressful parameters, and, therefore, they might be subject to higher evolutionary rates.

There is evidence for genes that act as regulators, keeping sections of the genome intact and providing some stability to the reproducing genome from generation to generation (Carson \& Templeton, 1984; Parsons, 1987). However, these genes are subject to mutation and selection just as are other genes and chromosomes. Most mutations in this self regulating system would be deleterious and not survive. However, at certain points in the history of a population a destabilizing mutation is more likely to survive and lead to the evolution of new forms.

There are populations of Hawaiian species, often on the older islands, which show little variation and appear to be in a stasis stage. At the same time there are other populations - even of the same (!) species - which are in a state of explo- 
sive change and are adapting to new habitats (Carson \& Ohta, 1981).

I believe that one of the major events allowing the survivorship of genotypes decoupled from their stabilizing regulatory genes is the ecological release from previously strong selection pressures, such as often occurs with a founder event or adaptive shift. When the release leads to a J-shaped population curve many genotypes, including changes in stabilizing genes, that are normally suppressed can survive and reproduce. Release from the stabilizing genes allows greater phenotypic variability upon which the new selection pressures can act. This scenario fits the adaptive shift model of cave adaptation, as well as the observed phenomena associated with recent colonizers (for example, the increase in the frequency of host changes and other adaptive shifts, as well as population crashes and the appearance of apparent poor fitness among some populations undergoing rapid expansion). This scenario also fits the predictions of the modern synthesis, since it envisions natural selection molding successful genomes from the accumulating random mutations and recombinations.

The theoretical effects on evolution of founder events and population bottlenecks have received considerable attention, but the effects of the possibly equally important and related phenomenon of explosive population buildup after bottlenecks are less appreciated (see review by Carson \& Templeton, 1984). Selection pressures favoring survival and reproduction among individuals in expanding populations, crashing large populations, and stable small populations are all very different; e.g. for crashing populations there are additional intense intraspecific competition and increased mortality factors. Thus, gene frequencies may change more dramatically and adaptive shifts may be more likely with fluctuating populations than with stable ones. Cave animals on Hawaii Island appear to have undergone frequent flush/crash population cycles after the initial founding event, as they were able to colonize young flows before they were extirpated from older ones. Thus, the colonization of caves on Hawaii Island agrees with the genetic model for speciation by founder effect outlined by Carson \& Templeton (1984).

\section{ACKNOWLEDGEMENTS}

I thank first Professors V. Sbordoni and M. Cobolli-Sbordoni, Roma, Italy, for organizing this Symposium and for their hospitality during my stay there; Professor C. Juberthie and his staff at Moulis, France, for their hospitality and helpful discussions on the manuscript; Drs. F.D. Stone and S.E. Miller, and Ms N.C. Howarth, Honolulu, U.S.A., for helpful discussions and suggestions on the manuscript. Field work in Australia was supported 
by Dupont (Australia) Co., The Explorer's Club, and The Chillagoe Caving Club. Part of the research reported herein was supported by National Science Foundation Grant BSR-85-15183 to F.G. Howarth.

\section{REFERENCES}

AHEARN, G.A. and F.G. HOWARTH. 1982. Physiology of cave arthropods in Hawaii. J. Experim. Zool. 222: 227-238.

BARR, T.C., Jr. 1968. Cave ecology and the evolution of troglobites. Evol. Biol. 2: 35-102.

BARR, T.C., Jr. and J.R. HOLSINGER. 1985. Speciation in cave faunas. Ann. Rev. Ecol. Syst. 16: 313-337.

BERGER, A.J. and D.V. HOWARD. 1968. Anophthalmia in the American robin. The Condor 70: 386-387.

CARSON, H.L., L.S. CHANG, and T.W. LYTTLE. 1982. Decay of female sexual behavior under parthenogenesis. Science 218: 68-70.

CARSON, H.L. and A.T. OHTA. 1981. Origin of the genetic basis of colonizing ability. pp. 365-370. In G.G.E. SCUDDER and J.L. REVEAL (eds.), Evolution today: Proc. 2nd Internatl. Congr. Syst. Evol. Biol. Hunt Inst. Bot. Doc., Carnegie-Mellon Univ. Pittsburg, PA.

CARSON, H.L. and A.R. TEMPLETON. 1984. Genetic revolutions in relation to speciation phenomena: the founding of new populations. Ann. Rev. Ecol. Syst. 15: 97-131.

CHAPMAN, P. 1986. Non-relictual cavernicolous invertebrates in tropical Asian and Australasian Caves. pp. 161-163. In Comision Organizadora del IX Congreso Intern. Espeleol. (ed.), vol. 2, Proc. $9^{\circ}$ Congreso Internacional de Espeleologia, Barcelona, Espana, 1986. Barcelona: C./Badajos, 145-147.

CHRISTIANSEN, K. 1986. Regressive evolution in Collembola. NSS Bulletin 47: 89-100.

CULVER, D.C. 1982. Cave Life. Evolution and Ecology. Harvard Univ. Press, Cambridge, MA. X. 190 pp.

FENNAH, R.G. 1973. The cavernicolous fauna of Hawaiian lava tubes, 4. Two new blind Oliarus (Fulgoroidea: Cixiidae). Pac. Insects 15: 181-184.

FOWLER, C.W. and J.A. MACMAHON. 1982. Selective extinction and speciation: Their influence on the structure and functioning of communities and ecosystems. Am. Nat. 119: 480-498.

GAGNE, W.C. and F.G. HOWARTH. 1975. The cavernicolous fauna of Hawaiian lava tubes, 7. Emesinae or thread-legged bugs (Heteroptera: Reduviidae). Pac. Insects 16: 415-426.

GERTSCH, W.J. 1973. The cavernicolous fauna of Hawaiian lava tubes, 3. Araneae (spiders). Pac. Insects 15: 163-180.

GURNEY, A.B. and D.C. RENTZ. 1978. The cavernicolous fauna of Hawaiian lava tubes, 10. Crickets (Orthoptera: Gryllidae). Pac. Insects 18: 85-103.

HADLEY, N.F., G.A. AHEARN, and F.G. HOWARTH. 1981. Water and metabolic relations of cave-adapted and epigean lycosid spiders in Hawaii. J. Arachnol. 9: 215-222.

HOWARTH, F.G. 1979. Neogeoaeolian habitats on new lava flows on Hawaii Island: An ecosystem supported by windborne debris. Pac. Insects 20: 133-144.

HOWARTH, F.G. 1980. The zoogeography of specialized cave animals: a bioclimatic model. Evolution 34: 394-406.

HOWARTH, F.G. 1981. Non-relictual terrestrial troglobites in the tropical Hawaiian caves, pp. 539-541. In B. BECK, (ed.), Proc. 8th Internat. Cong. Speleol. Nat. Speleol. Soc., Huntsville, AL. 
HOWARTH, F.G. 1983a. Bioclimatic and geologic factors governing the evolution and distribution of Hawaiian cave insects. Entomol. Gen. 8: $17-26$.

HOWARTH, F.G. 1983b. Ecology of cave arthropods. Ann. Rev. Entomol. 28: 365-389.

HOWARTH, F.G.. 1986. The tropical cave environment and the evolution of troglobites. pp. 153-155. In Comision Organizadora del IX Congreso Intern. Espeleol. (ed.). vol. 2, Proc. $9^{\circ}$ Congreso Internacional de Espeleologia, Barcelona, Espana, 1986. Barcelona: C. / Badajos, 145-147.

HOWARTH, F.G. and F.D. STONE (in prep.). Elevated carbon dioxide levels in Bayliss Cave. Australia: Implications for the evolution of cave faunas. (Submitted, 1987)..

HUPPOP, K. 1986. The role of metabolism in the evolution of cave animals. NSS Bulletin 47: 136-146.

JUBERTHIE, C. 1983. Introduction, le Milieu souterrain: Etendue et composition. Mem. de. Biospeol. 10: 17-65.

MACDONALD, GA., A.T. ABBOTT and F.L. PETERSON 1983. Volcanoes in the Sea. The geology of Hawaii. 2nd edition, University of Hawaii Press, Honolulu. 517 pp.

NEVO, E. 1979. Adaptive convergence and divergence of subterranean mammals. Ann. Rev. Ecol. Syst. 10: 269-308.

PARSONS, P.A. 1987. Evolutionary rates under environmental stress. Evol. Biol. 21: 311-347.

POULSON, T.L. 1986. Evolutionary reduction by neutral mutations: Plausibility arguments and data from amblyopsid fishes and linyphiid spiders. NSS Bulletin 47: 109-117.

SBORDONI, V. 1982. Advances in speciation of cave animals. pp. 219-240. In Mechanisms of Speciation. Alan R. Liss, New York.

SIMON, C., W.C. GAGNE, F.G. HOWARTH, and F.J. RADOVSKY. 1984. Hawaii: A natural entomological laboratory. Bull. Entomol. Soc. Amer. 30 (3): 8-17.

SKET, B. 1986. Why all cave animals do not look alike - A discussion on adaptive value of reduction processes. NSS Bulletin 47: 78-85.

STEFFAN, W.A. 1973. Polymorphism in Plastosciara perniciosa. Science 182: $1265-1266$.

WILKENS, H. 1986. The tempo of regressive evolution: Studies of the eye reduction in stygobiont fishes and decapod crustaceans of the Gulf Coast and west Atlantic region. Stygol. 2: 130-143.

WILKENS, H. and K. HUPPOP. 1986. Sympatric speciation in cave fishes? Studies on a mixed population of epi- and hypogean Astyanax (Characidae, Pisces). Z.f. zool. Systematik u. Evolutionsforschung. 24: 223-230. 